\title{
Leprosy in Eastern Nigeria - Reflections on Cases Diagnosed at Uzuakoli i 959-64
}

\author{
S. G. BROW NE, M.D., F.R.G.P., F.R.G.s., D.T.M. \\ Leprosy Service Research Unit, Uzuakoli, Eastern Nigeria.
}

The anti-leprosy campaign in Eastern Nigeria has been the subject of reports by Lowe and Smith (1949), Lowe (1952), Davey (1957) and others, and the results of investigations undertaken in this Unit in furtherance of the general objectives of the campaign have been published from time to time. The pattern of leprosy as a disease most difficult to eradicate from a tropical country is now emerging. Control measures and comprehensive treatment facilities together result at first in a dramatic fall in the total number of patients and a notable reduction in the number of new cases diagnosed annually. Thereafter, control seems to become rather less effective, new cases tending to counterbalance discharges, and eradication of the disease is seen to be protracted as a task and remote as a goal.

During the period August, I 959, to December, I 964, I O I 5 persons were diagnosed at Uzuakoli as having leprosy. This figure represents about half of those who presented themselves with signs they considered indicative of the disease, or nearly $30 \%$ of the total number of new patients with leprosy diagnosed during this period in the Uzuakoli leprosy control area (3477), the remainder having been seen at the district clinics. This paper will examine in detail only the IOI5 patients diagnosed at Uzuakoli itself.

No trends are discernible in the total number of new patients diagnosed from year to year, or in the proportions of the different varieties of leprosy, as the table in next column indicates.

Reasons given for coming to the Diagnostic Clinic

Although it may be difficult to discover the real reason, or combination of reasons, that brought the individual patient to the point of presenting himself at the Diagnostic Clinic, the following were given, in the approximate

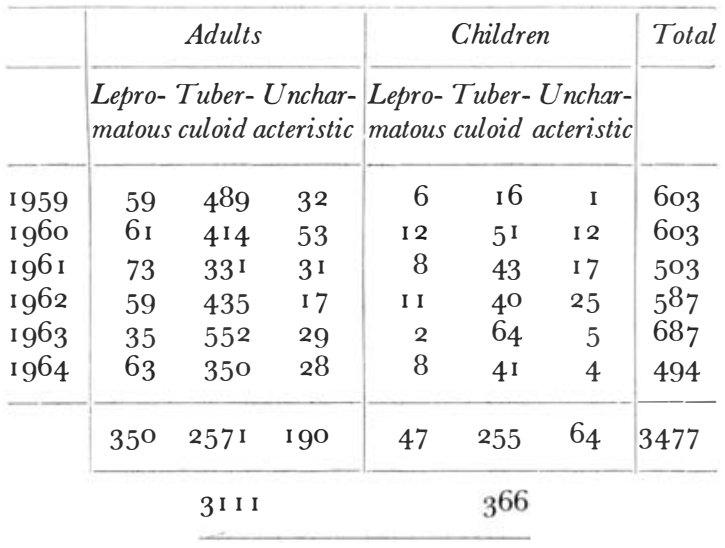

Totals :

Lepromatous

Tuberculoid 397 patients, I $1.4 \%$

Uncharacteristic $\quad 254 \quad, \quad 7 \cdot 3 \%$

N.B. Annual returns (U.N.I.C.E.F.) are made according to the above categories.

order of frequency: lesions that failed to disappear with time or to show improvement on the application of indigenous irritants or Western caustics; appearance of new lesions or extension of existing lesions; development of nodulation in unnoticed macular lepromatous disease; nerve pain; acute exacerbation; dermatitis from self-medication; ulceration of anaesthetic extremities; acute foot-drop, lagophthalmos, facial paralysis, or sudden paresis of the intrinsic muscles of the hand; epistaxis and nasal obstruction. Pressure to seek medical advice might be exerted on the patient by near relatives, neighbours or local government officials.

Delay in seeking treatment

In general, the more obvious and the more easily recognizable the lesion, the shorter the 
delay in seeking help. Thus, frank tuberculoid lesions of the uncovered skin (especially the face and forearms) may bring the patient to the Diagnostic Clinic within a few months, whereas the generalized macular rash of lepromatous leprosy may remain unnoticed for several years. In fact, the commonest clinical finding in lepromatous leprosy nowadays in this district is a coalescent macular rash that leaves unaffected only small areas in the groins, the sacral region, the axillae and the scalp. In the ordinary contacts of everyday life in village and marketplace, these patients pass for the lighter-hued, and it may be only the occurrence of nodulation or of neuropathic ulceration that brings the patient for diagnosis and treatment.

Of the IOI5 patients in whom leprosy was diagnosed, 727 gave an indication of the time elapsing since they noticed some symptom or sign which they then or since attributed to leprosy: in 204 bacteriologically positive patients the average was 22 months, while in patients with tuberculoid or indeterminate lesions the average was I 5 months. These figures are underestimates, certainly by several months and possibly by years. They have a bearing, however, on the age of onset of leprosy in Nigeria, and indicate that the infective contact or contacts must antedate the coming of the patient for diagnosis by the variably long latent period plus the (underestimated) average period of delay in seeking medical advice.

\section{Epidemiological considerations}

The epidemiological implications of these facts will not escape notice: not only do bacilliferous patients disseminate Myco. leprae for many months among their entourage, but the identification of the source case of many new infections may be quite impossible.

Another disquieting feature is that an educated generation is arising that fails to recognize the less obvious stigmata of leprosy. The wily old chiefs and headmen detected and correctly appraised an early macular rash as 'the mother of the bad leprosy', whereas their modern counterparts do not see, or do not see the significance of, the lesions that are barely visible or recognizable.

The urgent and practical question arises: is a method of case-finding adequate that depends ultimately and predominantly on non-medical suspicion? By this method and ancillary measures, the prevalence of the disease can be reduced - possibly below a hypothetical critical level - but present experiences in Eastern Nigeria do not foster any sanguine hopes of complete control and eventual eradication unless a more effective and practicable method of case-finding can be utilized in the field.

\section{Bacterioscopic examination}

All patients presenting themselves at the Diagnostic Clinic are subjected to examination of material by the slitsmear method obtained from six or eight sites, including the ear-lobes and nasal mucosa and the suspected lesion or lesions. In the majority of patients, the findings, whether positive or negative, served as confirmatory evidence of the clinical diagnosis.

In certain cases, however, the examination was of more positive value; e.g., in demonstrating the extent and intensity of the infection in lepromatous leprosy; in revealing bacilli in patients provisionally classified as having indeterminate leprosy, which was in reality macular lepromatous leprosy; in showing bacilli, sometimes numerous and sometimes in clumps, in cases of tuberculoid leprosy in exacerbation; in indicating the intensity of bacillary infection in certain cases of borderline leprosy.

The following table indicates the numbers and proportion of patients with bacilli at one or more sites, as revealed by microscopical examination of material obtained by the slitsmear standard technique.

\begin{tabular}{lrrr} 
& $\begin{array}{c}\text { Total } \\
\text { number }\end{array}$ & $\begin{array}{c}\text { No. with } \\
\text { bacilli }\end{array}$ & $\begin{array}{c}\text { Bacteriologi- } \\
\text { cally positive }\end{array}$ \\
\hline Lepromatous & I45 & 1 39 & 96 \\
Borderline & I 53 & I Oo & 65 \\
Tuberculoid & 673 & I 2 & 2 \\
Indeterminate & 44 & 9 & 20 \\
\cline { 2 - 4 } & IOI5 & 260 & 26
\end{tabular}

Of the 6 patients with bacteriologically negative lepromatous disease, 5 were in children (ages: I, IO, II, I I, I 2) with multiple illdefined macular lesions that in Africa may suddenly become highly positive.

\section{I34 Leprosy Review}


Of the I 39 patients with bacteriologically positive lepromatous leprosy, in no fewer than I 22 all the 6 or 8 sites smeared were positive; in 3 , only one site was positive (ear-lobes 2, nasal mucosa $\mathrm{I}$ ), and in the remaining 9, two sites were positive (skin 8, ear-lobes 6, nasal mucosa 4). In most patients, there was no significant difference at the several sites smeared either in the absolute height of the Bacterial Index or in the Morphological Index (the proportion of morphologically normal forms). Where there was a marked difference, the skin showed the highest Index in 20 patients, the nasal mucosa in 18 , and the ear-lobes in 17 .

With expert techniques, examination of material from the contralateral ear lobe or the contralateral septal mucosa does not add appreciably to the precision of diagnosis of the assessment of the Bacterial Index. If circumstances dictated the minimum number of such examinations, then a single examination should be made from material taken from the most active edge of a recent lesion; the second most valuable examination would be of material from an ear-lobe, and the third of material from the septal mucosa.

Based on Dharmendra's notation (maximum 4.0), the following table indicates the Bacterial Index in the patients with lepromatous or borderline disease:

\begin{tabular}{ccc}
\hline $\begin{array}{c}\text { Average } \\
\text { Bacterial Index }\end{array}$ & $\begin{array}{c}\text { Lepromatous } \\
\text { Leprosy }\end{array}$ & $\begin{array}{c}\text { Borderline } \\
\text { Leprosy }\end{array}$ \\
\hline o- -0.9 & 27 & 74 \\
I -1.9 & 29 & 20 \\
$2-2.9$ & 40 & 6 \\
$3-4.0$ & 49 & 0 \\
\cline { 2 - 3 } & I 45 & 100 \\
\cline { 2 - 3 } Average: & 2.25 & 0.76
\end{tabular}

Of 666 sites smeared in Ioo patients with borderline leprosy, 43 I showed bacilli as follows: very scanty 33 , scanty I 27, I + I 44 , $2+89,3+37$ and $4+\mathrm{I}$.

The examination of the morphology of individual Myco. leprae in these initial routine smears was of interest. Sometimes the presence of a high proportion of grossly degenerate bacilli might indicate that treatment had been taken clandestinely, but the percentage of normal forms in the patient who had never had treatment might vary within wide limits, i.e. from o to $100 \%$. There may be an ebb and flow in the susceptibility of Myco. leprae to inimical factors, or in the intensity of these factors, resulting in changes in the proportion of morphologically normal forms of Myco. leprae encountered in routine smears made in untreated patients.

\section{Seasonal variation}

Attendances at the Diagnostic Clinic month by month show no great differences likely to be dependent on season, the farming calendar, or on any other discoverable factor. Taking into account the variable delay in seeking treatment, there is no indication that the onset of leprosy or the occurrence of exacerbation is associated with changes in temperature or humidity, as has been suspected elsewhere.

\section{Contacts}

The time-honoured concept of 'close and intimate contact' long held to be necessary if leprosy is to be contracted, cannot be deduced or supported from a study of the series under review. In only 66 instances out of Io I $5(6.5 \%)$ was any contact admitted or suspected. In a district that has been generously provided with treatment facilities for some years past, and in which the great majority of those suffering from active leprosy are probably under treatment, this low proportion admitting contact is probably accurate. The degree of contact varied from the intimate (mother-and-child) to the problematically remote and infrequent (neighbour in the same compound). The suspected or presumed index case was usually abacilliferous to standard methods of examination, and in most cases had probably been so always. The paucity of known patients arising in the families of highly positive patients, and the numbers of new patients in which no such sources are implicated, are alike remarkable. There may be an unsuspected source of infection, or an unrecognized bacilliferous case, or even possibly an extra-human 'réservoir de virus'.

The epidemiological and practical importance of these considerations needs no emphasis. In particular, the regular examination of close contacts of a bacilliferous index patient may be economically sound, but it will not lead to the discovery of more than a small proportion of patients with leprosy in such a community and at such a stage in the history of the endemic. 
The value of yaws survey and resurveys

It has been the practice to attach an auxiliary versed in leprosy, to itinerant yaws teams engaged in whole-population surveys and resurveys. The value of this procedure varies with the experience of the auxiliary and the thoroughness he displays in examination, and also with the state of the anti-leprosy campaign in the district concerned. Thus, in the neighbourhood of Uzuakoli, yaws teams directed to the Diagnostic Clinic only i 6 patients suspected of having leprosy, and half of these proved to be either ex-patients whose lesions were residual or persons whose lesions had regressed spontaneously. In the remoter southern districts, however, where a greater number of patients with active leprosy remained undiagnosed and untreated, 70 patients needing treatment for leprosy were in one area directed to the district clinics.

\section{Treatment recommended for the patients}

The organisation of the anti-leprosy campaign provides for treatment as follows: as in-patients at Uzuakoli Settlement; at district leprosy clinics, the patient residing either in his own home or in a segregation village adjacent to the clinic; treatment prescribed from Uzuakoli, the patient coming for periodical clinical and bacteriological examination ('confidential treatment').

The choice of the appropriate course for the individual patient depends on medical and social factors, particularly the contagiousness of the patient and the home circumstances. A well-run Welfare Service, with indigenous auxiliaries attached to each group of district clinics, provides all relevant information concerning social factors.

Patients with the more contagious or potentially serious forms of leprosy (lepromatous or borderline) are advised to enter Uzuakoli Settlement; the same advice is given to those undergoing acute exacerbation of any form of leprosy, acute neuritis, any eye complication or paresis. Children are frequently admitted on social rather than on strictly medical grounds, so that they are spared the mental suffering of village ostracism and exclusion from school because of a leprosy infection, of ten relatively benign. Some patients are admitted because of neuropathic ulceration, or the need for surgical intervention, or the provision of footwear, after a sequestrectomy for example.

The accompanying table indicates the disposal of the IOI 5 patients, analysed according to the type of leprosy from which they were suffering.

\begin{tabular}{|c|c|c|c|c|c|}
\hline & $\begin{array}{l}\text { Lepro- } \\
\text { matous }\end{array}$ & $\begin{array}{l}\text { Border- } \\
\text { line }\end{array}$ & $\begin{array}{l}\text { Tuber- } \\
\text { culoid }\end{array}$ & $\begin{array}{l}\text { Indeter- } \\
\text { minate }\end{array}$ & Total \\
\hline \multicolumn{6}{|l|}{ Uzuakoli } \\
\hline Settlement & I30 & I 3 I & 217 & I 9 & 497 \\
\hline District Clinics & I 2 & 19 & 292 & I 9 & $34^{2}$ \\
\hline \multirow{4}{*}{$\begin{array}{l}\text { 'Confidential' } \\
\text { treatment } \\
\text { No treatment } \\
\text { advised }\end{array}$} & & & & & \\
\hline & I & 3 & 43 & 5 & $5^{2}$ \\
\hline & 2 & - & I 2 I & I & I 24 \\
\hline & 145 & I 53 & 673 & 44 & IOI 5 \\
\hline
\end{tabular}

\section{'No treatment advised'}

In no fewer than I 24 patients in this series, no treatment was advised because their lesions were inactive. They had come because of pressure from relatives, neighbours or officials, or because of appearances they mistook for evidence of activity. More than half did not know how long they had had the quiescent leprosy lesions. Most of the 57 patients who had some idea of the duration of the leprosy lesions fall into two main categories: those with completely inactive residual lesions they knew to have been present for several years (24 patients), and those with early lesions regressing spontaneously (26 patients). The history and clinical indications were imprecise in the remaining seven patients. Knowledge of the natural history of the disease in West Africa and of the probable consequences of the decision not to treat is a sine qua non in dealing with these patients.

\section{Neuropathic ulceration}

Ulceration of the extremities, usually the lower, sometimes the upper, and sometimes both lower and upper, was present in 93 patients when they came to the Diagnostic Clinic. Some ulcers were obviously of long standing, whereas others were of recent appearance and had made the patient or his neighbours realize that something was amiss.

While secretion from ulcers rarely contains acidfast organisms, neuropathic ulceration 
occurred in 34 patients whose skin smears were bacteriologically positive: I 2 out of I 4 patients with lepromatous leprosy, i 9 out of 25 with borderline, and three out of 54 with tuberculoid.

S U M M A R Y

To judge from experience during the past five years at Uzuakoli, the anti-leprosy campaign in Eastern Nigeria has entered a difficult phase in which many sporadic cases of leprosy are still appearing. The reasons for this state of affairs and its epidemiological implications are considered.

Certain clinical and bacterioscopic aspects of the problem are recorded, and recommendations made regarding case-finding, slit-smear examination, etc.

\section{A GKN OWLEDGEMENTS}

I wish here to pay tribute to all those who have assisted in whatever capacity in the anti-leprosy campaign in Eastern Nigeria. My thanks are due to Dr S. O. Egwuatu, Chief Medical Officer, Ministry of Health, Eastern Nigeria, for permission to publish this article:

\section{REFERENGES}

DAvey, T. F., Int. 7. Leprosy, 25, 329, I 957.

LOWE, J., West Afr. med. J., r, I, 1952.

LOWE, J., and smith, J., Int. 7. Leprosy, r 7, i 8 I I (149. 